\title{
コンクリートの熱特性值の測定と二，三の考察 \\ EXPERIMENTAL STUDIES ON THERMAL PROPERTIES OF CONCRETE
}

\section{1. 緒言}

コンクリートの熱的諸性質は, コンクリート体内部の 温度分布, 温度応力, ひびわれ発生などを理論的に解明 するための基礎的資料である。したがって，温度変化が 生ずるコンクリート構造物の設計，施工を合理的に行な らために，これらに関するより正確な特性值を知ること はきわめて重要である。

米国内務省開拓局は, Boulder ダムの建設にあたり， ダムコンクリートの熱拡散率, 熱伝導率, および比熱の 測定方法 および測定值に関する報告書 ${ }^{1)}$ を出版した。 Thomson $^{2)}$ は, コンクリートあるいは岩石の円柱形供 試体について, 空中泠却法による熱拡散率の測定方法を 提案した。西沢 ${ }^{3)}$ は, コンクリートの熱抬散率を水中冷 却法および空中泠却法の 2 方法によって測定し, 結果の

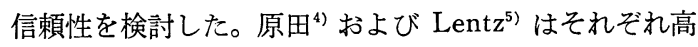
温時および低温時におけるコンクリートの熱伝導率の変 化を研究した。Campbell ${ }^{6}$, Missenard ${ }^{7)}$, 斎藤 ${ }^{8)}$ は, コンクリートを構成する各物質の配置を単純にモデル化 した場合の熱伝導に関する理論的研究を行なった。その ほか, コンクリートの熱的性質に及ぼす配合条件, 混和 材，骨材の石質などの影響に関する多くの 報告 ${ }^{92}$ 22) が ある。

以上のように, 既往の研究内容は, 熱的性質の測定方 法および結果の信頼性, コンクリートの組織を単純にモ デル化した場合の熱伝導理論, 特定な構造物を対象とし た熱的性質, 材料の種類, 配合, 養生方法などの諸条件 を限定した場合の熱的性質, などであって，いまだ明ら かにされていない面が多く, また, 広範囲にわたり系統 的に研究されているとはいえないのが現状である。

本研究は, コンクリートの熱的性質に関する研究の一

* 正会員 工修 秋田大学助教授 鉱山学部土木工学科 ** 正会員 工修 秋田大学助手 鉱山学部土木工学科
徳 田 弘* · 庄 谷 征 美** By Hiroshi Tokuda and Masami Shōya

環として行なったもので, その範囲は次のとおりであ る。ポルトランドセメント, フライアッシュ, 各種骨材 を種々に組合わせて使用したコンクリート，モルタル， およびセメントペーストの配合 387 種を定め, これらの すべてについて熱拡散率を測定し，一部について熱伝導 率を測定した。測定時における供試体の含水状態は飽水 状態であった。さらに, 両特性值およびコンクリートの 単位容積重量から比熱を推定した。これらの結果に基づ き, 骨材量と熱的諸性質との関係, 熱抬散率と熱伝導率 との関係, 比熱とコンクリートの単位容積重量との関倸 が明らかとなった。コンクリートの熱抬散率および熱伝 導率の測定方法を比較すれば，供試体の製造，実験装置 の規模, 測定に要する時間, などの諸点において, 前者 は後者よりかなり有利である。したがって，熱拡散率の みを測定すれば，上記関係から他の特性值を推定するこ とが可能である。また，コンクリートは熱拡散率の異な るセメントペーストと骨材とからなる不均質材料である から，その熱拡散現象を解明するには，均等質材料の場 合とは違った手法が必要であろう。したがって, 本研究 では, 熱拡散率について, これを種々の角度から究明し た。すなわち, 配合諸条件が熱拡散率におよぼす影響, 混和材料を使用した場合の熱拡散率，コンクリートを複 合材料としての観点からみた場合の熱抎散率, 細粗骨材 自身の熱拡散率の間接測定, 骨材の石質による岩石学的 分類と熱拡散率との関係, などである。

\section{2. 実験方法}

\section{（1）使用材料および配合}

セメントは普通ポルトランドセメント 6 種, 中庸熱ポ ルトランドセメント 11 種, 混和材はフライアッシュ 5 種, 混和剤は F, P , V の 3 種であった。細骨材は普通 17 種, 軽量 5 種, 合計 22 種であり, 粗骨材は普通 24 
表一1 細骨材の品質

\begin{tabular}{|c|c|c|c|c|c|}
\hline & 記 号 & 産 地 & 比 重 & $\begin{array}{l}\text { 吸水量 } \\
(\%)\end{array}$ & 石 \\
\hline 1 & S 1 & 神奈川 & 2.63 & 2.45 & $\begin{array}{l}\text { 砂䂠，硬砂岩，チャート，安山岩 }\end{array}$ \\
\hline 2 & KO 1 & 宮 崎 & 2.64 & 1.10 & 硬＼cjkstart砂＼cjkstart岩 \\
\hline 3 & $\mathrm{KE}$ & 高 知 & 2.59 & 1.20 & 珪 \\
\hline 4 & $\mathrm{H} \mathrm{I}$ & 岡 山 & 2.56 & 2.62 & 玢 \\
\hline 5 & AN & 北海道 & 2.57 & 1.98 & 安山 \\
\hline 6 & $\mathrm{SE}$ & 広 島 & 2.67 & 0.81 & 石 可 \\
\hline 7 & KU & 北海道 & 2.85 & 1.39 & 角 閃 \\
\hline 8 & $\mathrm{AK}$ & 長 野 & 2.64 & 0.94 & 花 嫡 岩 \\
\hline 9 & S 2 & 長 野 & 2.63 & 1.26 & $\begin{array}{l}\text { 砂蒚, 鿓㟶, チ岩 } \\
\text { 岩, }\end{array}$ \\
\hline 10 & $\mathrm{HA}$ & 山口 & 2.59 & 0.96 & 石 英 斑 岩 \\
\hline 11 & $\mathrm{GE}$ & 北海道 & 2.68 & 2.02 & 玄武 岩 \\
\hline 12 & K I & 福 島 & 2.73 & 2.07 & 輝 \\
\hline 13 & S A 1 & 北海道 & 2.60 & 2.13 & 砂 \\
\hline 14 & S A 2 & 和歌山 & 2.56 & 2.60 & 砂 \\
\hline 15 & KO 2 & 宮 崎 & 2.60 & 1.68 & 砂 \\
\hline 16 & $Z \mathbf{A}$ & 北海道 & 2.44 & 4.15 & 火山 灰 \\
\hline 17 & L 1 & 東 京 & 1.92 & 12.5 & 人 工 軽 骨 \\
\hline 18 & L 2 & 東 京 & 1.88 & 12.7 & 人工 軽 骨 \\
\hline 19 & PA & 北海道 & 0.56 & & パーライト \\
\hline 20 & S 3 & 北海道 & 2.62 & 1.38 & 砂岩, 安山岩, 頁岩, チ \\
\hline 21 & S 4 & 秋 田 & 2.58 & 2.65 & 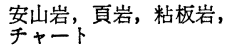 \\
\hline 22 & L 3 & 東 京 & 2.02 & 12.6 & 人 工 軽 骨 \\
\hline
\end{tabular}

種, 軽量 6 種, 重量 2 種, モデル 2 種, 合計 34 種で あった。これらの骨材の産地, 比重, 吸水量の石質, お よび記号を 表一1，2 亿示す。細骨材のうち, S 1 S 4 は天然砂, L 1 L 3, ZA, PA は軽量砂, そのほかは砕 砂である。粗骨材のうち, G 1 G 4 は天然砂利, L 1 I 4, ZA, PA は軽量粗骨材, JU, JI は重量砕石, M 1, M 2 はモデル粗骨材, そのほかは砕石である。モデル 粗骨材は, 普通ポルトランドセメントと豊浦標準砂を用 いて製造したモルタル板をコンクリートカッターで各種 寸法のほぼ立方形に切断して製造したものであって, あ らかじめその熱拡散率を測定しておいた。 M1 および $\mathrm{M} 2$ の配合は，それぞれ $W / C=0.58, S / C=2 / 1$ およ び $W / C=0.30, S / C=1 / 4$ であり，熱拡散率はそれぞれ $278 \times 10^{-5}$ および $168 \times 10^{-5} \mathrm{~m}^{2} / \mathrm{hr}$ であった。

使用した細粗骨材の粒度は標準粒度をほぼ満足するも のであった。

コンクリートの配合を次のようにして決定した。すな わち, 基本となる配合を定め, 次にこの配合における単 位骨材量の一部を減じ，残る材料と空気量との和が単位 体積となるように各成分をそれぞれの絶対容積に比例し て増加させた配合を定める。このようにして, 段階的に 骨材量を減じ，モルタルあるいはセメントペーストにい たるいくつかの配合を定める。次に，基本配合における 骨材量を増し，それにともなって残る各成分を減少させ た配合も定める。以上のようにして，一連の配合が定め られる。各配合シリーズにおいて，単位骨材量が小さく なるにつれて，コンクリートあるいはモルタルの流動性
表一2 粗骨材の品筫

\begin{tabular}{|c|c|c|c|c|c|}
\hline No. & 記 号 & 産 地 & 比 重 & $\begin{array}{c}\text { 吸水量 } \\
(\%)\end{array}$ & 石 \\
\hline 1 & G 1 & 神奈川 & 2.71 & 0.80 & $\begin{array}{l}\text { 硬砂岩, 安山岩, チャー } \\
\text { 卜, 珪質粘板岩, 砂岩 }\end{array}$ \\
\hline 2 & KO 1 & 宮 崎 & 2.67 & 0.60 & 硬＼cjkstart砂＼cjkstart岩 \\
\hline 3 & $\mathrm{KE}$ & 高 知 & 2.64 & 0.51 & 珪岩 \\
\hline 4 & $\mathrm{H} \mathrm{I}$ & 岡 山 & 2.64 & 1.26 & 玢 \\
\hline 5 & AN 1 & 北海道 & 2.53 & 1.76 & 安山 \\
\hline 6 & SE 1 & 広 島 & 2.71 & 0.14 & 石 屁 \\
\hline 7 & $\mathrm{KU}$ & 北海道 & 2.92 & 0.74 & 角 閃 \\
\hline 8 & KA 1 & 長 野 & 2.65 & 0.60 & 花＼cjkstart崗＼cjkstart岩 \\
\hline 9 & G 2 & 長 野 & 2.66 & 0.63 & $\begin{array}{l}\text { 砂岩, 頁岩, チャート, } \\
\text { 花岩, 岩山虏 }\end{array}$ \\
\hline 10 & $\mathrm{HA}$ & 山 口 & 2.61 & 0.89 & 石 英 斑 岩 \\
\hline 11 & GE & 北海道 & 2.73 & 1.57 & 玄武岩 \\
\hline 12 & K I & 福 島 & 2.80 & 1.02 & 緑岩 \\
\hline 13 & S A 1 & 北海道 & 2.69 & 1.04 & 岩 \\
\hline 14 & S A 2 & 和歌山 & 2.60 & 1.51 & 砂 \\
\hline 15 & KO 2 & 宮 崎 & 2.71 & 0.95 & 砂 岩 \\
\hline 16 & $Z \mathrm{~A}$ & 北海道 & 1.29 & 18.3 & 火山 磷 \\
\hline 17 & L 1 & 東 京 & 1.40 & 9.44 & 人工軽 骨 \\
\hline 18 & L 2 & 東 京 & 1.34 & 9.50 & 人工軽 骨 \\
\hline 19 & PA & 北海道 & 0.22 & - & パーラ ト ト \\
\hline 20 & G 3 & 神奈川 & 2.64 & 0.79 & $\begin{array}{l}\text { 硬砂岩, 珪買, 粘板岩, } \\
\text { チャート, }\end{array}$ \\
\hline 21 & KA 2 & 長 野 & 2.61 & 0.67 & 花＼cjkstart崗＼cjkstart岩 \\
\hline 22 & $\mathrm{NE}$ & 静 風 & 2.68 & 0.98 & 砂質粘板岩 \\
\hline 23 & $\mathrm{HE}$ & 福 井 & 2.80 & 0.47 & 片麻岩 \\
\hline 24 & S A 3 & 福 井 & 2.57 & 2.06 & 砂 \\
\hline 25 & L 3 & 東 京 & 1.80 & 14.0 & 人工軽 骨 \\
\hline 26 & $\mathrm{~J} \mathrm{U}$ & 北海道 & 3.70 & 1.01 & 重 晶 石 \\
\hline 27 & J I & 岡 山 & 4.85 & 0.30 & 磁鉄 鉱 \\
\hline 28 & G 4 & 北海道 & 2.52 & 2.74 & $\begin{array}{l}\text { 安山岩, 砂岩, 硬砂岩, } \\
\text { チャート }\end{array}$ \\
\hline 29 & $\mathrm{AN} 2$ & 北海道 & 2.59 & 1.17 & 安 山 \\
\hline 30 & SE 2 & 北海道 & 2.68 & 0.64 & 石 屁 \\
\hline 31 & AN 3 & 秋 田 & 2.54 & 4.41 & 安 山 岩 \\
\hline 32 & L 4 & 東 京 & 1.60 & 9.61 & 人 工 軽 骨 \\
\hline 33 & M 1 & 秋 田 & 2.16 & 14.3 & セメントモルタル \\
\hline 34 & M 2 & 秋 田 & 2.21 & 14.6 & セメントモルタル \\
\hline
\end{tabular}

は大きくなる傾向が認められた。なお，同一配合シリー ズでは, 同種の細骨材および同種の粗骨材を使用した。

\section{（2） 熱拡散率およひ熱伝導率の測定方法}

コンクリートの練りまぜには可傾式ミキサを使用し た。供試体の楸生方法は $21^{\circ} \mathrm{C}$ 水中養生とし, 材令 7 日 で熱的性質を測定した。

熱拡散率測定用供試体は，骨材最大寸法 $30 \mathrm{~mm}$ 以上 のコンクリートの場合 $\phi 15 \times 30 \mathrm{~cm}, 30 \mathrm{~mm}$ 以下の場合 $\phi 10 \times 20 \mathrm{~cm}$ であった。コンクリートを型わくへ詰める 際, 型わく高さの $1 / 2$ の水平断面中心部一径 $0.32 \mathrm{~mm}$, 長さ $3 \mathrm{~m}$ の銅コンスタンタン熱電対の先端感温部を埋 め込んだ。同一条件について，供試体個数は，セメント ペーストおよびモルタルの場合 2 個，コンクリートの場 合 4 6 個とした。測定方法は Glover の方法 ${ }^{1)}$ であっ て, 高さと直径の比が 2 の円柱形供試体を温湯中で一様 な温度分布となるまで熱した後，ただちに冷水中に入 れ，時間の経過にともなら供試体中心の温度変化を求 
め, この時間温度曲線から熱拡散率が得られる。なお, 温湯および泠却水の温度を, それぞれ $45 \sim 55^{\circ} \mathrm{C}$ および $15 \sim 20^{\circ} \mathrm{C}$ とした。

熱伝導率測定用供試体 は内径 $a=6 \mathrm{~cm}$, 外径 $b=20$ $\mathrm{cm}$, 高さ $L=40 \mathrm{~cm}$ の円筒形である。同一条件につい て供試体個数は 2 個とした。測定方法は直接法 ${ }^{1)}$ であっ て, 供試体中空部分の水をヒーターで加熱することに よって, 放射状の熱流を生ぜしめ, 同時に側面を冷却水 によって一定温度に保った。内面温度 $\theta_{a}$ および側面温 度 $\theta_{b}$ が一定值となったとき，ヒーターにおける電圧 $V$ および電流 $A$ を測定し, 熱の流動速度 $q(=A \cdot V \times$ 0.860) を求め, 次式から熱伝導率 $K$ を計算した。

$$
K=\frac{q \cdot \log _{e}(b / a)}{2 \pi L\left(\theta_{a}-\theta_{b}\right)}
$$

なお，供試体中空部分および冷却水の温度を，それぞれ $35 \sim 45^{\circ} \mathrm{C}$ および $15 \sim 20^{\circ} \mathrm{C}$ とした。

熱拡散率および熱伝導率の測定精度を示すため, 平均 測定值からのばらつきを求めたが，2６\% 程度であっ た。

\section{3. 実験結果および考察}

\section{（1）単位骨材量と熱的諸性質との関係}

細粗骨材の石質が同じ場合，単位骨材量の絶対容積と コンクリートの熱抬散率との関係を図一1 に示す。図中 の各点は測定值の平均であり, (1)〜211 は配合シリーズ

$\nabla_{A}\left(m^{3}\right)$
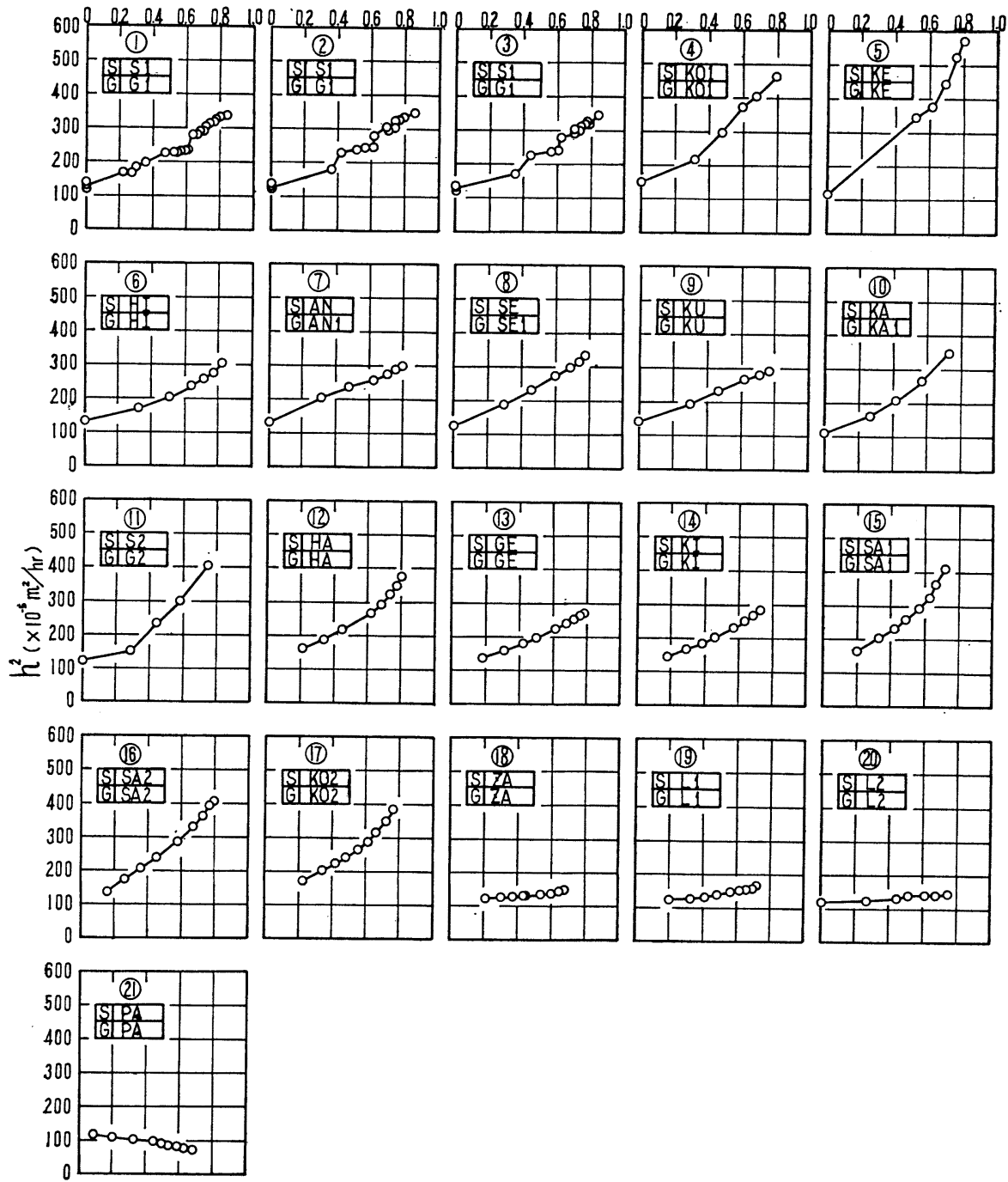
を示す。熱拡散率は骨材量の増加とともにほぼ一定の割 合で増加あるいは減少する傾向があり，この傾向は使用 骨材の石質によって異なる場合がある。骨材の熱拡散率 がセメントペーストのそれに比較して大きいときは増加 傾向, 小さいときは減少傾向を示すのであって, 両者の 差が大きいほど骨材量の増加に伴う熱拡散率の増加ある いは減少の割合が大きくなると考えられる。図一2 は骨 材量と熱伝導率との関係であって, 熱拡散率に関する上 記結果と同様な傾向が認められる。同図に, 熱抎散率 $h^{2}\left(\mathrm{~m}^{2} / \mathrm{hr}\right)$, 熱伝導率 $K\left(\mathrm{kcal} / \mathrm{m} \cdot \mathrm{hr} \cdot{ }^{\circ} \mathrm{C}\right)$ および単位容 積重量 $\rho\left(\mathrm{kg} / \mathrm{m}^{3}\right)$ から次式によって比熱 $C(\mathrm{kcal} / \mathrm{kg}$ ・ $\left.{ }^{\circ} \mathrm{C}\right)$ を求めた結果を併記した。

$$
C=\frac{K}{h^{2} \cdot \rho}
$$

図から, 比熱は, 骨材量の増加に伴って増加あるいは減 少の傾向を示す熱伝導率と全く逆の傾向を示すことが明 らかである。コンクリートの熱的諸性質は, 測定時にお ける温度条件によって変わるといわれている(1),9)。本研 究では, 同一温度条件で熱拡散率と熱伝導率を測定して いるとはいえないので，厳密には上式を適用できないの であって, 得られた特性值は便宜的なものである。

細粗骨材の石質が異なるとき, 骨材量の増加に伴。 て, モルタルからコンクリートに移ると熱拡散率の増加 あるいは減少の傾向が急変する場合がある。これは細粗 骨材の熱拡散率が等しくないからであろらと考える。し たがって，モルタル部分をセメントペーストと細骨材の
混合物, コンクリート部分をモルタルと粗骨材の混合物 として扱うのが合理的である。図一3 は，細骨材および 粗骨材の 絶対容積と熱拡散率との関係であり, 図一4 は，同様にして，熱伝導率および比熱を示したものであ る。コンクリート部分における熱拡散率の変化の模様 は，使用粗骨材およびモルタル両成分の熱拡散率によっ て決まるのであって, これについては（5）において詳述 する。

骨材量 と熱拡散率との関係を分類して示せば，図一5 のような 4 つのパターンになる。は細粗骨材の石質 が同じ場合であり， B， C ，(D) は両骨材の石質が異なる

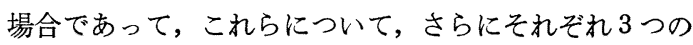
パターンが考えられる。

\section{（2）熱拡散率と熱伝導率との関係および比熱と 単位容積重量との関係}

図一1，3 の熱拡散率 $h^{2}\left(\mathrm{~m}^{2} / \mathrm{hr}\right)$ と図一2，4の熱伝 導率 $K\left(\mathrm{kcal} / \mathrm{m} \cdot \mathrm{hr} \cdot{ }^{\circ} \mathrm{C}\right)$ を同一配合シリーズについて比 較すると，その模様はきわめて近似している。図一6 は 両者の関係を示すもので, 265 点がプロットされてい る。これに原点を通る直線式をあてはめると式 (3) のよ うになり, 同式を用いて熱伝導率を推定するときの標準 誤差は $0.156 \mathrm{kcal} / \mathrm{m} \cdot \mathrm{hr} \cdot{ }^{\circ} \mathrm{C}$ である。

$$
\text { or } \left.\begin{array}{c}
h^{2}=0.00138 K \\
K=725 \cdot h^{2}
\end{array}\right\}
$$

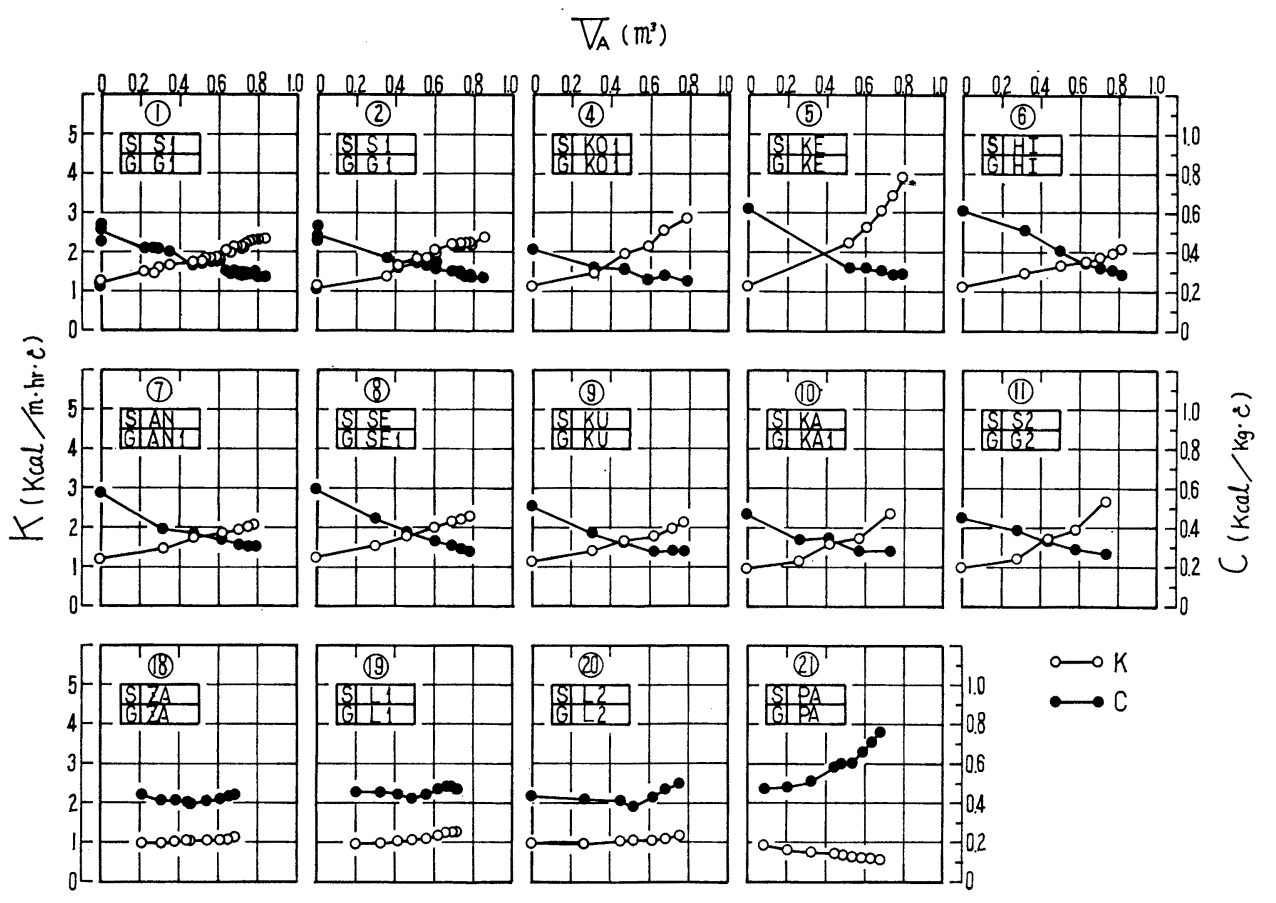

図一2 コンクリートの単位骨材量 $V_{A}$ と熱伝導率 $K$ および比熱 $C$ との関係 

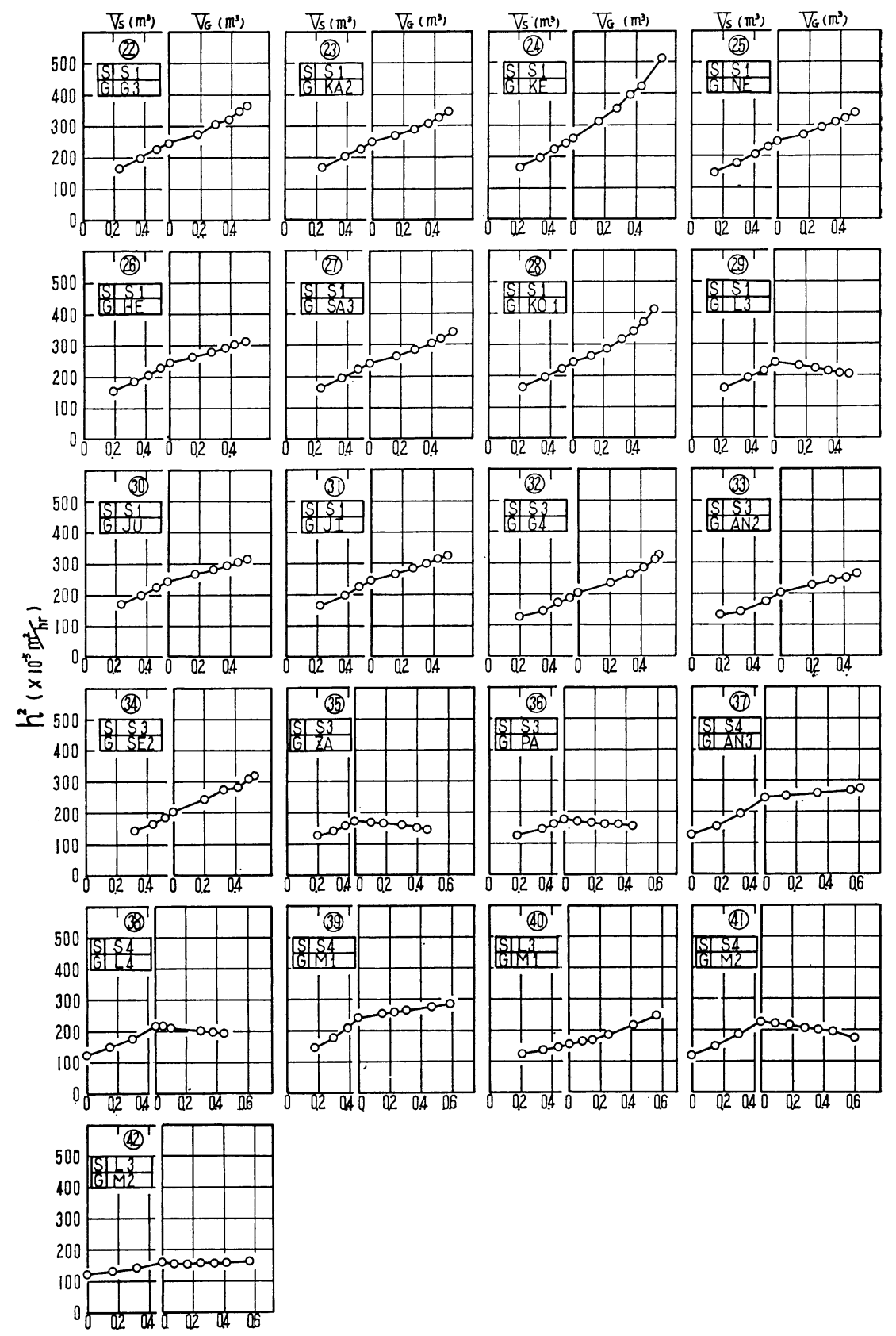

図一3 コンクリートの単位細骨材量 $V_{S}$ および単位粗骨材量 $V_{G}$ と熱拡散率 $\boldsymbol{h}^{2}$ の関係

図一2,4 に示されている比熱 $C\left(\mathrm{kcal} / \mathrm{kg} \cdot{ }^{\circ} \mathrm{C}\right)$ とコンク リートの単位容積重量 $\rho\left(\mathrm{kg} / \mathrm{m}^{3}\right)$ との関係を図一7 に示 す。図中には 265 点がプロットされている。式 (2), (3) から式 (4) が得られるが，同式を用いて比熱を推定する 場合の標準誤差は $0.040 \mathrm{kcal} / \mathrm{kg} \cdot{ }^{\circ} \mathrm{C}$ である。

$$
C=\frac{725}{\rho}
$$

式 (3)，(4) に抒いて, 両辺のディメンションが一致し
ないが，定数のそれは式 $(2)$ から $\left(\mathrm{kcal} / \mathrm{m}^{3} \cdot{ }^{\circ} \mathrm{C}\right)$ である ことがわかる。

\section{（3）コンクリートの配合が熱拡散率に及ぼす影響}

配合シリーズ 1 は, 混和材料を使用しないプレーンコ ンクリートの配合であって, 水セメント比, 骨材最大寸 法, 単位骨材量などの配合諸条件が熱拡散率に及ぼす影 響を明らかにする目的で定めた配合である。水セメント 


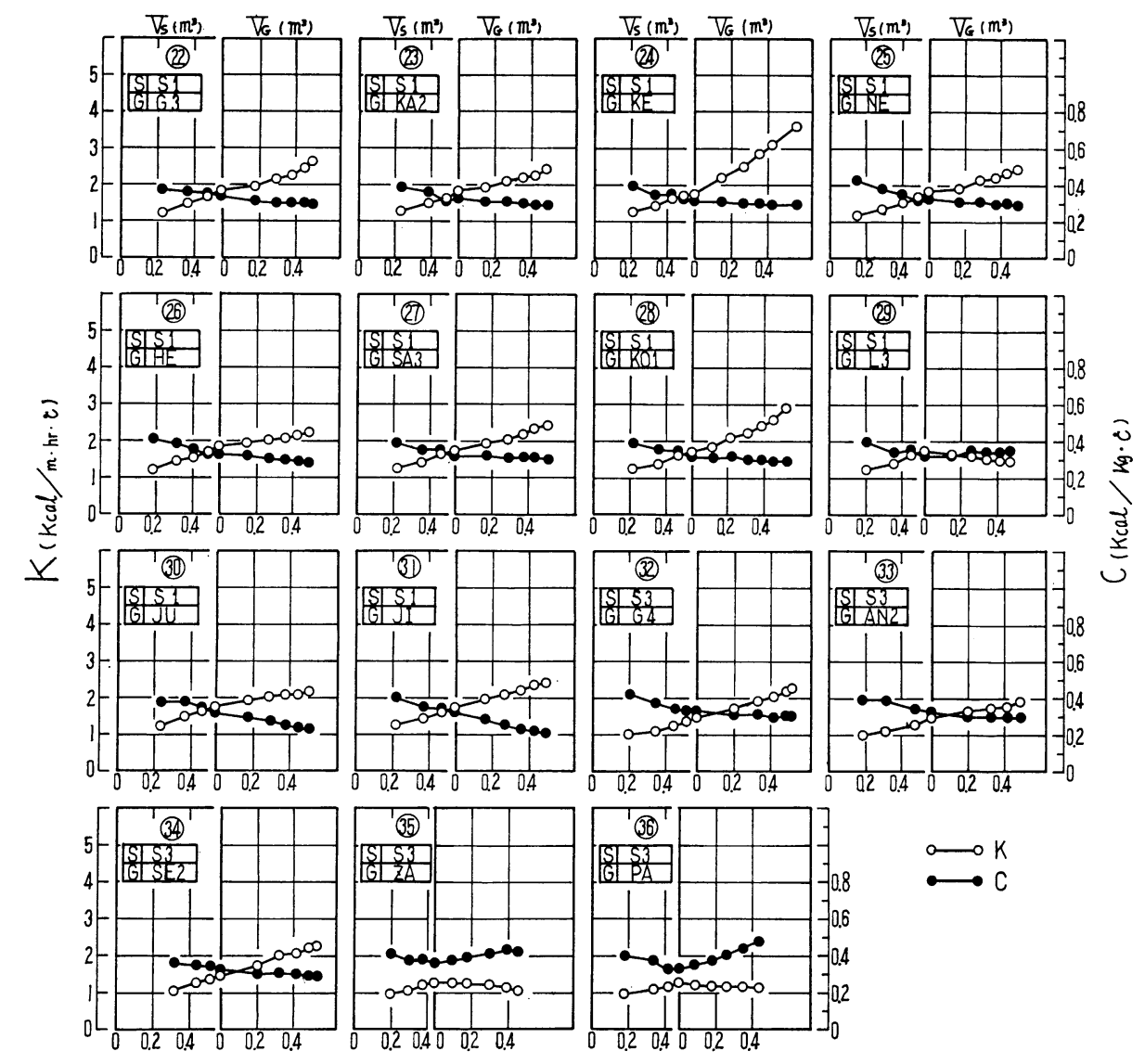

図一4 コンクリートの単位細骨材量 $V_{S}$ および単位粗骨材量 $V_{G}$ と熱伝導率 $K$ および比熱 $C$ の関係

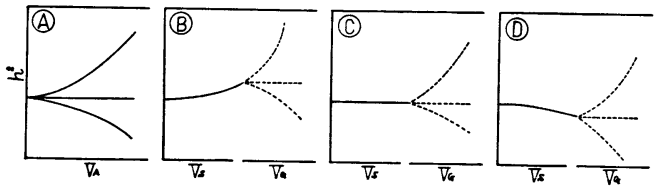

図一5 骨材量と熱拡散率の関係の分類

比と熱拡散率との関係を図一8に示す。同図から，水セ メント比が大きくなればセメントペーストの熱拡散率は 小さくなるし，モルタルおよびコンクリートのそれは大 きくなる傾向が認められる。この原因は，水セメント比 が大きくなれば，七メントペーストの場合，その容積の 中に占める自由水の割合が大きくなるからであり，モル タルおよびュンクリートの場合, 骨材の占める体積が大 きくなるからであろうと考えられる。セメントペースト 硬化体の熱拡散率は，水のそれより大きく，河川産骨材 のそれより小さいことが明らかである ${ }^{9}$ 。たとえば，骨 材最大寸法 $40 \mathrm{~mm}$ のコンクリートの場合, 水セメント 比が $35 \%$ から 75\% に変わると, 骨材容積は約 10\%, 熱拡散率は約 7\% それぞれ増加する。両増分が一致し ない理由の一つとして, 上述の水セメント比とセメント

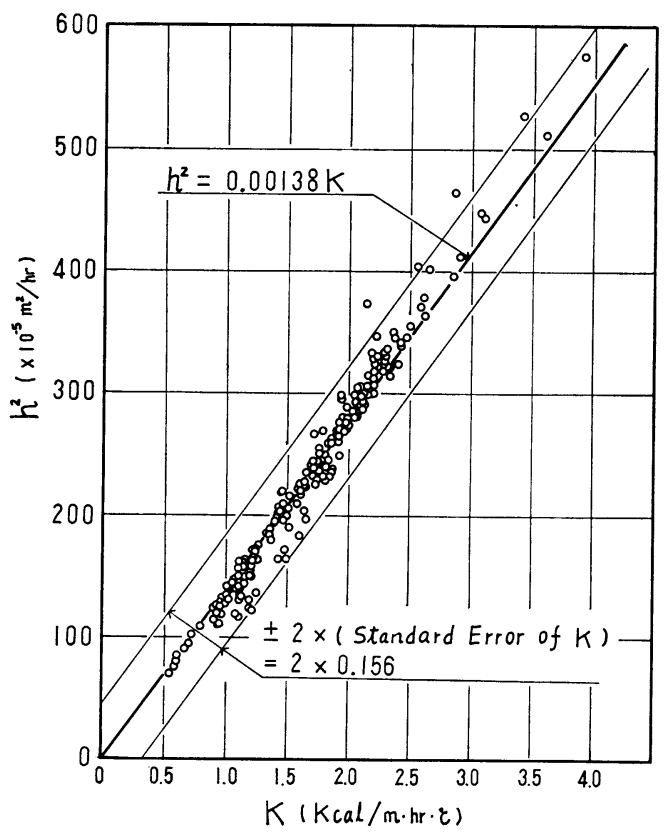

図一6 熱云導率 $K$ と熱拡散率 $h^{2}$ の関係 


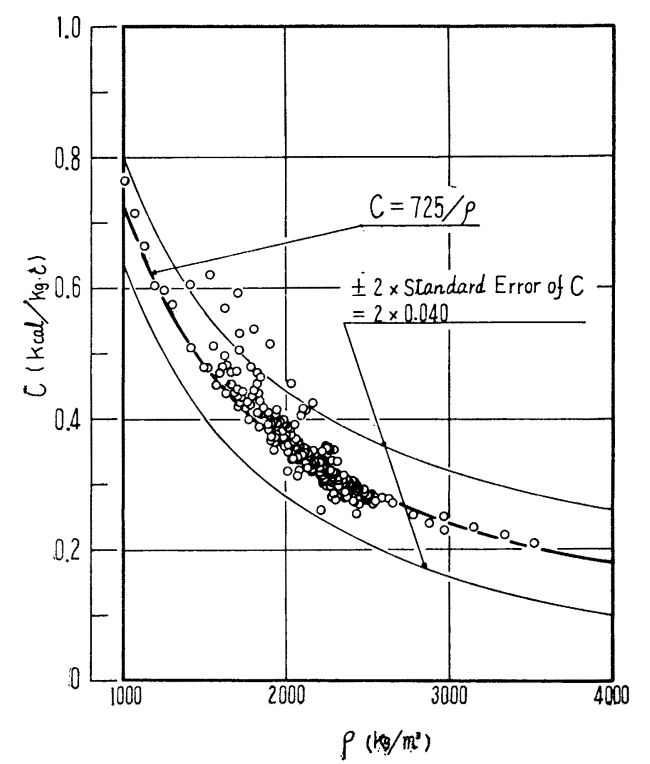

図一7 コンクリートの単位容積重量 $\rho$ と比熱 $C$ の関係

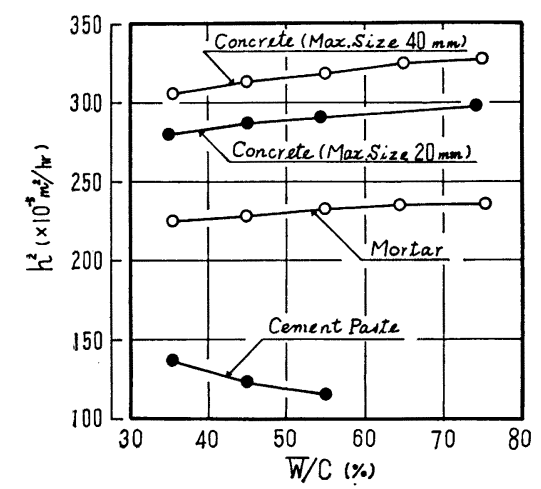

図一8 コンクリートの水セメント比 $W / C$ と 熱拡散率 $\boldsymbol{h}^{2}$ の関係

ペーストの熱拡散率との関係が考えられる。また, 細粗 骨材の石質が同じで，その熱拡散率がセメントペースト のそれより大きいとき，骨材最大寸法が大きくなるほど 単位骨材量は増加するから，コンクリートの熱拡散率は 増加するのであって，このことは図一8および図一1，3 からも明らかに認められる。

\section{（4）混和材料が熱拡散率に及ぼす影響}

配合シリーズ 2,3 は, 混和材としてフライアッシュ を内割でそれぞれ $50 \% ， 30 \%$ 混和したコンクリートの 配合である。図一1 (1), (2), (3) を比較すると, セメント ペーストの熱拡散率は 3 者ほとんど等しく, 骨材量と熱 拡散率との関係にも顕著な 差異は認められない。した がって, フライアッシュコンクリートとプレーンコンク リートの熱拡散率はほとんど同等であると判断される。 この原因は次のと抢りであろうと思われる。すなわち，
プレーンコンクリートと同一コンシステンシーのフライ アッシュコンクリートをつくるには, 単位水量をかなり 減じなければならない。単位セメント量 $(C+F)$ を一 定としたとき，セメント量を同重量のフライアッシュで おきかえると,フライアッシュの比重はセメントのそれ より小さいので, $(C+F)$ の容積はおきかえ前より大き くなる。したがって, 単位骨材量は, コンクリートの熱 拡散率を大きく変えるほど著しい増減はないのである。

次に，混和剤を使用した場合について考える。たとえ ば, 減水剂 $P$ の使用によって, セメント量約 10\%, 水 量約 15\% それぞれ減ずることができ, 連行空気量は約 $3 \%$ となる。配合シリーズ1のコンクリートについて, セメント, 水, および空気量をそれぞれ上記だけ増減さ せると，その結果は抢よそ0 となるから，骨材量は変化 しない。また, 空気量の多少は, 通常の範囲では, 熱拡 散率に大きな影響を及ぼさないこと音が明らかである。 したがって，混和剤を使用しても，コンクリートの熱拡 散率が大きく変わることはないであるうと思われる。

\section{（5）複合材料としてのコンクリートの熱拡散率}

既述のとおり，骨材自身の熱拡散率がこれを用いたコ ンクリートの熱抎散率にかなり大きな影響を及ぼす。し かしながら, 骨材の熱拡散率は一般に不明であって, こ れを直接測定することは可能である ${ }^{2}$ が，供試体の製造 などに困難な点が多く, 非常にむずかしい。そこで著者 らは，セメントモルタルによって熱拡散率が既知のモデ ル粗骨材 M 1，M 2 を製造した。これらを用いたコン クリートの熱拡散率測定結果は図一3 (39)〜位)のとおりで ある。この結果を複合材料としての見地から検討した。 すなわち，コンクリートをモルタルと粗骨材の両素材か ら構成される複合材料と仮定する。コンクリートから粗

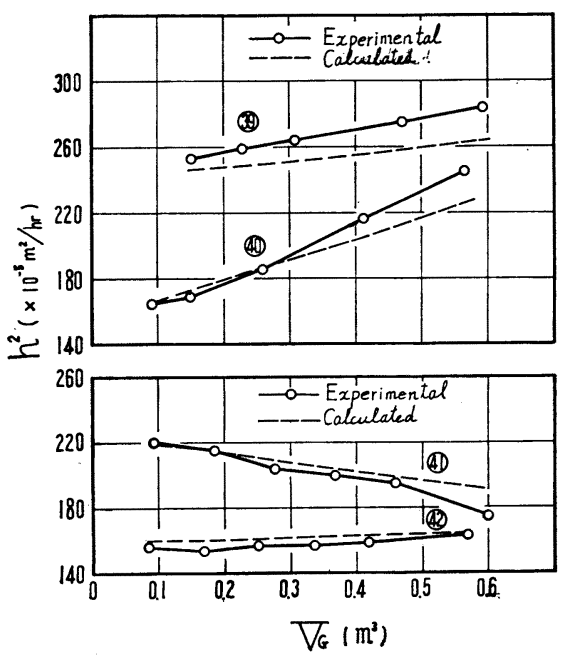

図一9 熱拡散率の実測値と推定值の比較 
骨材を除去し，残りのモルタル部分が単位体積となるよ らに換算する。この換算配合のモルタルの熱拡散率はす でに得られている当該配合シリーズの一連の熱拡散率測 定結果からただちに求められる。コンクリートの熱拡散 率は素材の熱拡散率とその絶対容積の積に比例すると仮 定し, 両素材について求めたこれらの積の和をコンク リートの熱拡散率の推定值とした。図一9 は, この推定 值と実測值とを比較した結果で，実測值との差は数％ を越えない。このような誤差が生じた原因として，骨材 量と熱抬散率との関係が必ずしも直線的でないこと，熱 拡散率の測定誤差が存在すること，などが考えられる。

しかし, 数％の推定誤差を認めることにすれば, 上記 の考え方は非常に有効であると考える。

\section{（6）細粗骨材の熱拡散率}

前節において, コンクリートの熱抎散率に及ぼす各構 成素材の影響は，それぞれの素材の熱抬散率と絶対容積 の積に比例することが実験的に明らかとなった。した がって, コンクリートの熱拡散率とその構成素材である モルタルの熱拡散率が既知であれば，粗骨材の熱抬散率 を求めることができる。さらに，上記の考え方を発展さ せて，モルタルをセメントペーストと細骨材からなる複 合材料と仮定すれば，セメントペーストおよびモルタル の熱拡散率を知って, 細骨材の熱拡散率を推定すること ができる。このようにして得られた細粗骨材自身の熱拡 散率を表一3に示す。ただし，セメントペーストは水セ メント比が大きくなると分離が著しく, 測定值の信頼性 に問題があると考えられたため, 測定を割愛したものが ある。これらについては，モルタル部分の骨材量と熱拡 散率との関係からセメントペーストのそれを近似的に図 上で求めた。セメントペーストの熱拡散率は，一般に $100 \sim 150 \times 10^{-5} \mathrm{~m}^{2} / \mathrm{hr}$ であって, 平均 $130 \times 10^{-5} \mathrm{~m}^{2} / \mathrm{hr}$ 程度である ${ }^{16)}$ から，近似的には，この值を用いてよいと 考えられる。表一3 は，わが国においてごく普通に産す る岩石の成因, 化学成分などを基準とした分類法 ${ }^{23}$ 亿準 じて本研究に用いた骨材を配列した結果であって，骨材 の熱抎散率および比重を併記した。ただし，天然骨材， 人工軽量骨材，および重量骨材に対して本分類法は適用 できないが，参考のため，人工軽量骨材のデータも表示 した。同表から骨材の熱拡散率に関する普遍的な規則性 を導くには，さらに多くのデータの積み重ねが必要と思 われる。しかし，おおむね次のような傾向が認められ る。火成岩についてみれば，花崗岩，石英斑岩などのよ らに $\mathrm{SiO}_{2}$ を多く含む岩石は, 玄武岩, 角閃岩など $\mathrm{SiO}_{2}$ 含有量の比較的少ないものより熱拡散率が大きい。この ことは, 沈積岩, 変成岩についても同様であって, 珪 岩, 砂岩, 砂質粘板岩などの熱拡散率はかなり大きい值
表一3 細粗骨材の熱拡散率 $h^{2}\left(\times 10^{-5} \mathrm{~m}^{2} / \mathrm{hr}\right)$ および比重 S.G.

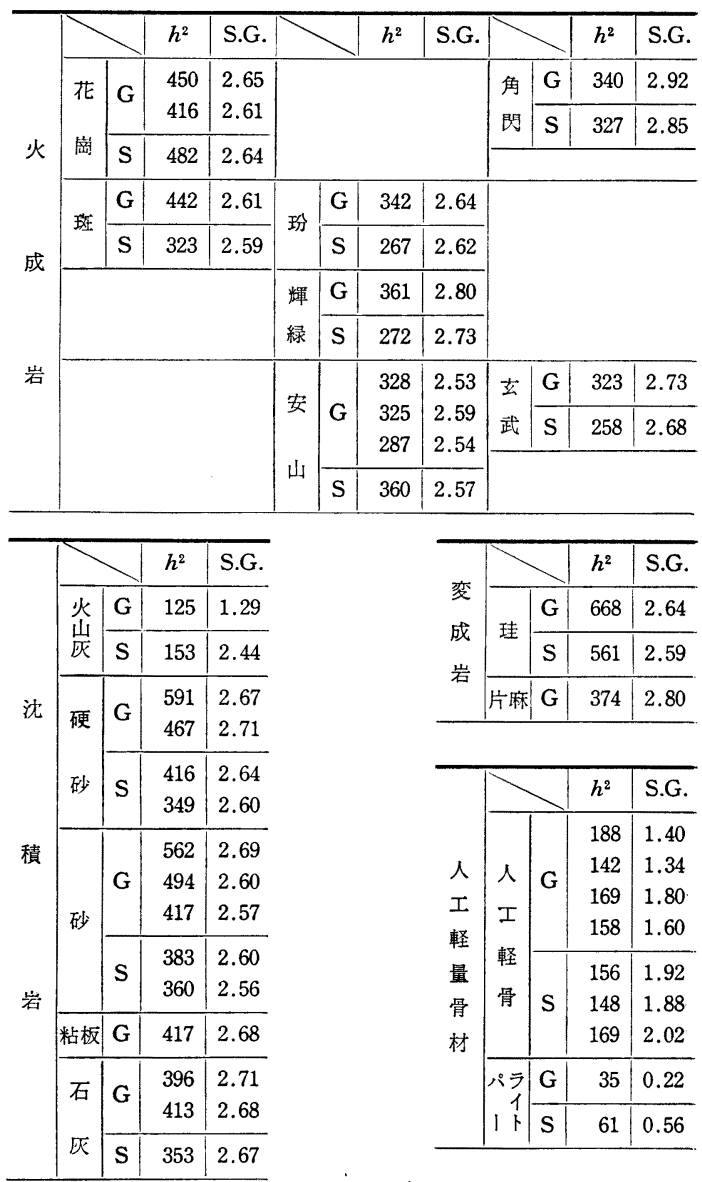

である。火山灰，人工軽量骨材などは，一般に $\mathrm{SiO}_{2}$ を 多く含むといわれているが，熱拡散率は非常に小さい。 これは，骨材の組織がポーラスなためであると考える。 同種の岩石の熱抬散率は, 比重の大きなものほど大きい ようである。石灰岩のように, $\mathrm{SiO}_{2}$ 含有量の小さいも のでも大きな熱拡散率を示すものがある。以上のよ5 に, 同表は使用骨材の熱拡散率を推定する際の目安を与 えるものと考える。

\section{4. 結言}

コンクリート構造物の設計, 施工の際に必要な材料の 諸性質に関する基礎的資料のうち, コンクリートおよび 骨材の熱的性質に関するものが非常に 重要な場合があ る。しかし，この種の研究報告はきわめて少なく，いま だに明らかにされていない面が多い。本研究は, コンク リートの熱的性質に関する研究の一環として行なったも のであって，各種材料を用いたコンクリート，モルタ ル，およびセメントペーストの配合 387 種を定め, これ 
らについて熱拡散率および熱伝導率を測定し，比熱を推 定した結果をとりまとめたものである。特にコンクリー トおよび骨材の熱払散率について，これを種々の角度か ら究明した。それらの結果を要約すれば，次のようにな る。

（1）細粗骨材の石質が同じ場合, コンクリートの熱 拡散率および熱伝導率は, 骨材量の増加とともにほぼ一 定の割合で増加あるいは減少する傾向がある。骨材の熱 拡散率がセメントペーストのそれに比較して大きいとき は増加傾向, 小さいときは減少の傾向を示すのであっ て，両者の差が大きいほどその割合は大きくなると考え られる。細粗骨材の石質が異なる場合, 骨材量の増加に ともなう熱拡散率および熱伝導率の変化は, モルタル部 分とコンクリート部分とで違った傾向を示す場合があ る。これは両骨材の熱拡散率が大きく異なるからであろ うと考えられる。また, 比熱の変化は, 熱拡散率, 熱伝 導率と全く逆の傾向を示す。

（2）熱拡散率 $h^{2}\left(\mathrm{~m}^{2} / \mathrm{hr}\right)$ と熱伝導率 $K(\mathrm{kcal} / \mathrm{m} \cdot \mathrm{hr}$. $\left.{ }^{\circ} \mathrm{C}\right)$ との間には次式 (1) が成立する。両測定法を比較 すると前者が後者より簡便かつ迅速であるから, 前者を 知って後者を推定するほうが有利であって，その場合の 標準誤差は $0.156 \mathrm{kcal} / \mathrm{m} \cdot \mathrm{hr} \cdot{ }^{\circ} \mathrm{C}$ である。

$$
K=725 \cdot h^{2} \cdot \cdots
$$

比熱 $C\left(\mathrm{kcal} / \mathrm{kg} \cdot{ }^{\circ} \mathrm{C}\right)$ とコンクリートの単位容積重量 $\rho\left(\mathrm{kg} / \mathrm{m}^{3}\right)$ との間には次式 (2) が成立する。同式を用い て比熱を推定するときの標準誤差は $0.040 \mathrm{kcal} / \mathrm{kg} \cdot{ }^{\circ} \mathrm{C}$ である。

$$
C=\frac{725}{\rho}
$$

（3）一般に, 水セメント比が大きくなれば，セメン トペーストの熱搪散率は小さくなるし, モルタルおよび コンクリートのそれは大きくなる傾向を示す。また，細 粗骨材の石質が同じで，その熱拡散率がセメントペース トのぞれより大きな場合, 骨材最大寸法が大きいほど単 位骨材量は増すので, コンクリートの熱拡散率は大きく なる傾向を示す。

（4）混和材料として，フライアッシュあるいは減水 剂を用いたコンクリートの熱拡散率は，これを混和しな いコンクリートのそれとほとんど同等であると考えられ る。

（5）コンクリートをモルタルと粗骨材の両素材から なる複合材料と仮定すると，コンクリートの熱拡散率に 及ぼす各構成素材の影響は，それぞれの素材の熱拡散率 と絶対容積の積化比例する。したがって両素材について 求めたこれらの積の和はコンクリートの熱拡散率の推定 值を与える。また，コンクリートおよびこれを構成する モルタル部分の熱拡散率が既知であるとき，粗骨材の熱
拡散率を推定できるし，モルタルがセメントペーストと 細骨材の両素材からなると仮定すれば，モルタルおよび セメントペーストの熱拡散率を知って, 細骨材の熱拡散 率を推定できる。なお，セメントペーストの熱拡散率を 近似的に $130 \times 10^{-5} \mathrm{~m}^{2} / \mathrm{hr}$ としてよい。両推定值とも， 平均值からのばらつきは数％以下であった。このよう にして, 従来, きわめて困難とされていた骨材自身の熱 拡散率を容易に推定できる。

（6）前記方法によって求めた 細粗骨材の 熱拡散率 は，石灰岩を除く普通骨材の場合， $\mathrm{SiO}_{2}$ 含有量の多い ものほど大きい值を示す。同種の石質については, 比重 が大きいほどその熱拡散率は大きくなるよらである。

本研究の一部は, 著者の 1 人が財団法人電力中央研究 所, 函館工業高等専門学校に在職中に行なったもので, 関係各位のご指導,ご協力に対し厚くお礼申し上げます。

\section{参 考 文 献}

1) Bureau of Reclamation, United States Department of the Interior: Boulder Canyon Project Final Reports, Part VII-Cement and Concrete Investigations, Bulletin 1, Thermal Properties of Concrete, 1940.

2) Thomson, W.T. : A Method of Measuring Thermal Diffusivity and Conductivity of Stone and Concrete, Proc. of A.S.T.M., Vol, 40, 1940.

3）西沢紀昭：コンクリートおよびモルタルの熱拡散率測定 方法に関する実験報告, 電研所報, $\mathrm{Vol}, 4$, No. 2, pp. $1 \sim 11,1954$.

4）原田 有：高温度におけるセメントモルタルおよびニン クリートの熱伝導率の変化, 日本建築学会研究報告, No. 49, pp. 1 8, 1954 .

5) Lentz, A.E. and G.E. Monfore : Thermal Conductivity of Concrete at Very Low Temperatures, Jour. of PCA Research and Development Laboratories, pp. 39 46, May, 1965.

6) Campbell-Allen, D. and C.P. Thorne: The Thermal Conductivity of Concrete, Magazine of Concrete Research, Vol. 15, No. 43, pp. 39 48, March, 1963.

7) Missenard, A. : Researches Théoriques et Expérimentales sur la Conductivité Thermique des Bétons, Annales de l'Institut Technique du Bâtiment et des Travaux Publics, Nos. 211-212, pp. 949 968, JuilletAoût, 1965.

8）斉藤 武・岡垣 理：湿った物質の伝熱特性，日本機械 学会誌, Vol. 62 , No. 484 , pp. $75 \sim 81$, 昭和 34 年 5 月.

9）西 忠雄・有坂正典 : 軽量コンクリートの熱伝導率一特 に含水を異にする場合, 構造用軽量コンクリートシンポ ジウム, 日本 $\mathrm{ACI}$, 昭和 39 年 11 月.

10）徳田 弘・伊藤 勉：人工軽量骨材を用いたコンクリー トの熱的性質について, 土木学会コンクリートライブラ リー No. 10 , pp. $26 \sim 31$, 昭和 39 年.

11）徳田 弘：パーライトコンクリートおよび火山灰コンク リートの 2,3 の性質, 土木学会第 21 回年次学術講演会 概要集, 第IV部, pp. 70-1 70-2, 昭和 41 年.

12）中条金兵衛・佐治健治郎 - 本間栄五郎：原子炉遮蔽用工 ンクリートの熱特性に関する研究, 日本セメント（株） 研究所要報, No. 164, 昭和 32 年 8 月. 
13）德田 弘・庄谷征美 : 複合材料としてのコンクリートの 熱拡散率, 日本材料学会第 21 期学術講演会講演概要集, pp. $73 \sim 74$, 昭和 47 年 5 月.

14）徳田 弘・庄谷征美・国分修一：膨張性セメント 混和材 を用いたコンクリートの熱拡散率に関する研究, 土木学 会膨張性セメント混和材を用いたコンクリートに関する シンポジウム, 昭和 47 年 8 月.

15）長谷川英雄・長坂普美夫：コンクリートの熱的性質に関 する 2,3 の実験, 土木学会第 19 回年次学術講演会概要 集, 第IV部, pp. 69-1 69-2, 昭和 39 年.

16）德田 弘・伊藤 勉: コンクリートの熱拡散率, 熱伝導 率, および比熱について, 電力中央研究所, 技術研究報 告 (土木 63014), 昭和 39 年 3 月.

17）德田 弘・伊藤 勉：コンクリートの熱拡散率に及ぼす 配合, フライアッシュ混和, および粗骨材の石質の影響, セメント技術年報, XVII, pp. 249 255, 昭和 38 年.

18) Tokuda, H. : Some Experimental Results on Thermal Properties of Concrete, Proc. of the 7 th J.C.T.M.,
The Society of Materials Science, Japan, pp. 122 123, 1964.

19) Tokuda, H. : Experimental Studies on Thermal Properties of Concrete, Proc. of the 8th J.C.T.M., The Society of Materials Science, Japan, pp. 112 114, 1965.

20) International Sub-Committee on Concrete for Large Dams : Collection of Data on the Thermal Properties of Concrete for Dams, 1958.

21) Mitchel, L.J. : Thermal Properties of Hardened Concrete, Significance of Tests and Properties of Concrete and Concrete Aggregates, A.S.T.M. STP No. 169, pp. 129 135, 1956.

22) Herbert K. Cook: Thermal Properties of Concrete Aggregates, A.S.T.M. STP No. 169, pp. 325 333, 1956.

23）土木学会編：土木工学ハンドブック (下巻), p. 2541, 昭 和 39 年.

(1972.8.21 • 受付) 